\title{
地域レジリエンスを考慮した 道路網の信頼性解析に基づく地震対策の評価
}

\author{
古田 均 1 ・中津 功一朗 2 ・高橋 亨輔 3 ・石橋 健 4 ・香川 圭明 5 \\ 1正会員＼cjkstart関西大学教授＼cjkstart総合情報学部総合情報学科（†569-1095 大阪府高槻市霊仙寺町2-1-1） \\ E-mail: furuta@ res.kutc.kansai-u.ac.jp \\ 2非会員 大阪城南女子短期大学常勤講師 現代生活学科（二546-0013 大阪市東住之江区湯里6丁目4-26） \\ E-mail: k-nakatsu@ jonan.ac.jp \\ 3正会員 香川大学危機管理研究センター 特命助教（†761-0396 香川県高松市林町2217-20） \\ E-mail: k_taka@eng.kagawa-u.ac.jp \\ 4正会員＼cjkstart関西大学ポスドク＼cjkstart総合情報学部総合情報学科（†569-1095 大阪府高槻市霊仙寺町2-1-1） \\ E-mail: ken_ishibashi@furuta-lab.jp \\ 5非会員 関西大学院生 総合情報学研究科知識情報学専攻（†569-1095 大阪府高槻市霊仙寺町2-1-1）
}

\begin{abstract}
本研究では, 地域のレジリエンスに着目し, 人命優先の観点に基づく道路ネットワークの信頼性解析か ら地震対策の評価を試みる。そして, 現行の緊急物資輸送に基づく対策と, 住民の安全性の確保を考慮し た本提案に基づく対策を比較する。このようにして, 本提案の対策が, 道路ネットワークの継続性を高め, 道路の分断や住民の孤立を防ぐことで，地域住民の安全性向上に繋がることを示す。地震対策において， 現行の計画を様々な観点から評価できることは，今後起こりうる震災の危機を把握し，被害を抑えていく ために必要不可欠である. 本研究より, 人命を優先した地震対策の評価が, 地域のレジリエンスを高める ための評価指標の1つとなりうることを示した.
\end{abstract}

Key Words : resilience, earthquake, road network, reliability analysis

\section{1. はじめに}

東日本大震災以降，災害対策の分野においてレジリエ ンスが注目されている1).レジリエンスとは，一般に継 続性や回復力と訳され，想定外の被害に対してしなやか に回復できる能力を意味する．地方自治体によって管理 されている道路ネットワークでは, 幹線道路や県間道路 のような緊急時の輸送路や広域への影響に基づいて策定 された計画に従って地震対策が行われている.そのため, 現在の道路網における地震対策は, 物資輸送などの広域 交通路を重視したものとなっている，たしかに，広域交 通路は大規模地震時において優先されるべきものである が，地方自治体は住民の安全性も考慮しなければならな い. したがって，住民の孤立や物資補給の妨げとなる道 路ネットワークの脆弱な箇所は地方自治体が住民の安全 を確保するために把握するべき事項である.

レジリエンスの考え方に基づく地震対策は，仮に想定 外の災害が発生としても被害を最小限に抑え, 早期復旧
を行い，復旧後の活動まで見通すものである．全ての災 害に対する一意な対策は存在しないため, PDCAサイク ルのように現状把握, 対策の見直しを通して議論を繰り 返し行っていく必要があるとされている. よって, 事業 や地域の継続計画の策定が重要とされており, 脆弱な箇 所の把握は, 現状の対策をよりレジリエントなものにし ていくための議論の材料として有効であるといえる. 本研究では, こうしたレジリエンスの観点から, 道路ネット ワークの安全性評価を試みる。この方法として住民の安全性を 重視して避難地，およひ防炎扰点の連結性に関寸る信頼性解析 を行い，その脆弱点を算出する. さらに, 数值シミュレーショ ンにおいて，算出した脆弱䇢所一刘策を施して信頼性解析を 再度害行する．これにより，災害時の道路ネットワークの継売 性を向上させ，地域住民にとって安全な道路ネットワークとす ることを示寸. 加えて, 復旧のシミュレーションを行い, ネッ トワークの絊売性が復旧に対して与える影響を調査する. 以上 より，災害発生後の活動を考慮した信頼性解析によって事前に 行う刘策を決定し，地震刘策を事前と事後の両面から見ること 
で，仮に想定外の災害が発生しても被害を最小限に抑え，しな やが回復するといったレジリエンス性の向上が可能かどうか 検討を行う. そして, 本提案加現状の地震文策の評価，及び市 ットワークのレジリエンスの向上に関する議論を深める一助と なりうることを示寸。

\section{2. レジリエンスと災害対策}

\section{(1) レジリエンスとは}

レジリエンスは，一般的に抵抗力，回復力と訳され， 脆弱性(vulnerability)の対義語であるとされる. 防災工学 分野においては, 東日本大震災以降, 内閣で事前防災・ 減災の考えに基づいたナショナル・レジリエンスが発足 されるなど，レジリエンスの考え方に着目した研究や取 り組みが行われている. Holling ${ }^{2)}$ は工学におけるレジリ エンスとして「摚乱後に以前の均衡状態に跳数返ること のできるシステムの能力」と定義した．さらに，

Birkmann ${ }^{3)}$ はハザード（危害要因）と脆弱性と暴露度の3 つの積でリスク (災害) を表し，それを災害リスクマネ ジメントで減じることをレジリエンスとしている.また, Norris ${ }^{4}$ は頑健性（Robustness）, 圥長性（Redundancy）, 迅速性（Rapidity）がストレス要因に対して反作用すると き，レジリエンスが起こると考えている。つまり，レジ リエンスとは，危機から回復する能力である.

想定外の環境変化において，特定の要素に対策をする だけではレジリエンスがあるとは言い難い．要素ひとつ の適応力を最大化するだけでなく, 要素同士が内包され 依存関係を持つ，いわばシステム全体での適応力を考慮 しなければならない，しかしながら，レジリエンスに関 わる構成要素は多く，かつ要素同士は極めて複雑な相互 依存関係を持つため，レジリエンスを定量的に評価する ことは難しい. システムの機能を何らかの形で定量化す ることが可能な場合，レジリエンスを「失われた機能を 時間軸上で積分したもの」と捉えることにより，定量化 する考え方もある5). たしかに，擋乱量を特定しシステ ムの機能䘫失を予測すれば定量化することはある程度可 能である. しかしながら，環境の大きな変化など想定す ることが難しい事象に対しては，システムのレジリエン スを事前に定量化しておくことは難しい.

一方で，レジリエンスの定量化が困難であったとして も，複数のシステムのレジリエンスを相対的に比較する ことが望ましい，環境変化に対する選択肢として複数の システムを提示寸ることで，レジリエンスを相対的に評 価し，採用することが可能である．防災におけるレジリ エンスは，日常と非常時の両方において，システム全体 とその構成要素を総合的に維持，および管理することが 重要となる。したがって, レジリエンスを考慮する対象
において，レジリエンスを向上させるための要素が何か を見出し，定めることが必要であるといえる.

\section{（2）地震対策におけるレジリエンス性}

レジリエンスの定量的評価を試みたBruneau ${ }^{5)}$ は，地震 対策におけるレジリエンス要素として次の四つを挙げて いる.

一つ目は，抵抗力（robustness）である．障害発生時の 機能性損失に悩まされずに済むような，ストレスに対す るシステムの持つ耐力を表す，障害に対する準備を予め 適切に行うことで，この抵抗力を高めることが可能であ る. 抵抗力を上昇させることで, 障害発生時の損失を最 小限に抑えられ，機能性維持が可能である. さらに，機 能性低下抑止は，抑止されない場合と比べて機能性回復 までの差を小さくすることができ，結果的に復旧性へと 繋がる.

二つ目は，咒長性（redundancy）である，障害に対す るシステムの持つ余裕を表す，呪長性向上は，機能的な 余裕や対応策の選択肢の多さによってシステムを安定へ 導くことが可能であり，障害に対して迅速な対応が可能 となる.

三つ目は，資源力（resourcefulness）である，脅威とな る障害が存在する際に, 対策の実行優先順位や移動可能 な資源を定義する力である. 障害発生時において, 適切 な対策の決定は必要不可欠である，また，予算制約や技 術者不足などの資源不足が発生した場合における代替資 源の手配の早さは，迅速な復旧性の回復に繋がる.

最後に，迅速性（rapidity）である. 障害発生時から目 的の機能性回復までの早さを示す，障害発生からの回復 の早さは, システムの信頼性に繋がる.

以上，これら四つのレジリエンスの要素を高めること ができれば，障害に強く，信頼性の高いシステムの構築 が可能となる. 本研究では, これらの要素を基に道路ネ ットワークを 1 つのシステムとして捉え, ネットワーク の信頼性として数值を算出し比較することで，レジリエ ンス性を考慮した道路ネットワークの評価を試みる.

\section{(3) 現在の地震対策とレジリエンス}

現在の災害対策は, 阪神大震災以降, リスクマネジメ ントと,クライシスマネジメントの考え方に基づいて災 害対策が施されている。この二つは，概念の重なりから 日本語において危機管理（Crisis Management）として一 本化されて扱われることがあるが異なる概念である.

リスクマネジメントは, 近年の社会の激しい変化に伴 い，かつて経験しなかった複雑，かつ高度なリスクが増 加することに対する企業の事業継続の考えである. リス クマネジメントの考え方は, リスクを特定することから 始まり, 特定したリスクを分析して, 発生頻度と影響度 
の観点から評価した後，発生頻度と影響度の積として求 まるリスクレベルに応じて対策を講じる一連のプロセス である。また，リスクが実際に発生した際に，リスクに よる被害を最小限に抑える活動を含み，リスクを組織的 に管理し損失などの回避や低減を図るプロセスである゙． つまり，危機に対する事前対策の考え方である．災害に おけるリスクマネジメントは，起こりうる損失を可能な 限り抑制するように事前に準備しておくことである。ま た，実際に発生した被害に対する補償や復旧・復興の方 法を準備しておくことである.しかしながら，東日本大 震災以降，人々は被害の発生を抑止するという防災の思 想の限界を知り，大規模災害に対しては，被害の発生・ 増大を可能な限り抑制しようとする減災の思想に立脚す る必要があるとも考えられている7).

クライシスマネジメントは，第一次世界大戦の戦争突 入あるいは戦線拡大，甚大な被害を招く事態へのエスカ レーションを防止することを目的として，その回避のた めの方策が検討されたことが起源とされる. 危機が起こ る前に危機に対応する姿勢や意思を明確にしなければ, 実際に危機が起こった際に対応することは不可能である. つまり, クライシスマネジメントとは，危機が発生した 際によ゙う対応するかという事後対策の考え方である。 日 本での災害におけるクライシスマネジメントは，ハード 面の耐震，免震基準作りから始まり，地域防災計画，防 災強化が施されている ${ }^{8)}$. 以上の二つの考え方が現在の 災害対策の基となっている. リスクマネジメントとクラ イシスマネジメントは, リスクを最小限に抑え，機能低 下が起きたとしても迅速な対応により回復を試みるとい う，システムにおいては一連のプロセスである場合が多 く，両者の一貫した評価と対策が望ましい.

しかしながら，リスクマネジメントとクライシスマネ ジメントでは，障害を発生させる要因の多様性から対策 事項が膨大となり，同時に扱うことは難しい. 自然災害 に関しても，地震，台風，火災など多岐にわたる。さら に，自然災害は計測不可能なリスクを定量的に評価する ことは困難であるため, リスクマネジメントとクライシ スマネジメントは総合的に評価されていない現状にある.

\section{3. 地震に対するレジリエンス性を考慮した道路 ネットワークの評価}

\section{(1) レジリエンスに基づく地震対策}

本研究では，2.(3)節の二つの概念を包括しうるレジリ エンスの考えに基づき, 災害対策の評価を行う.そして, 道路ネットワークの地震に対するレジリエンス性の向上 を試みる．2.(2)節における四つのレジリエンス要素の関 係性に基づき, 地震対策を備えと対応の $2 つ の$ 側面に分類
する，備えの面では，被害そのものを抑える防災と被害 を最小限に抑える減災が挙げられ，対応の面では，被害 を受けてもすぐに機能を回復できる早期復旧が考えられ る.

まず，備えの面における対策として，地震時における ネットワークの継続性を向上させる補強箇所の組み合わ せを求める.この際, 地震時における住宅地, 消防や病 院から各避難地への経路の状態からネットワークの稼働 判定を行い，その割合からネットワークの稼働率を算出 する.さらに，地震により分断されたネットワークから 住民の避難距離を算出することで，市民の安全性を考慮 しつつ，道路ネットワークの継続性を向上させる補強対 象の組夕合わせを求めることが可能となる.

次に，対応の面として，復旧シミュレーションによる 復旧日数の短縮を図る. 具体的には, 備えの面において 求められた対策対象の組み合わせをひとつの補強計画と してモデル化し，そのモデルに基づいて構造物の復旧日 数を求める復旧シミュレーションを行う。そして, 現行 の重要路を重視した対策で用いられる対象の組み合わせ に補強を行ったモデルと比較することで，本研究におけ る補強対象の組み合わせの決定法が有効であることを示 す.これにより, ネットワークとしての継続性, つまり, 本研究における対応の面からのレジリエンス性が，地震 からの迅速な復旧に繋がることが期待できる.

以上のことから，備えの面と対応の面を考慮した対策 が，地震に対して頑健性を持ち，その余裕から被害を最 小限に抑え，しなやかで迅速に回復する道路ネットワー クの構築を可能にすることを示す．地震に対する信頼性 解析では，連結性により重要区間を算定するもの9), 10)や, 被害予測などから移動時間への影響に着目する研究 ${ }^{11), 12)}$ が行われている. 前者は被害予測に基づく事前対策，後 者は災害発生後の減災対策である。これらに対して，本 提案は，災害発生直後とその後の活動を考慮して事前対 策を決定する。このようにして，信頼性解析がレジリエ ンス向上のための地震対策に有効であることを示す.

\section{（2）稼働率に基づくネットワーク継続性の評価}

本研究では，3.(1)節で述べた検証法の有用性を示すた めに，高槻市の一部をモデルとして用いた。このモデル におけるネットワークの信頼性の評価とその結果に基づ く継続性向上のための対策の検討を試みる. 強度と外力 を表-1に，対象のネットワークモデルを図-1に示す.

表-1 リンクの強度と外力の確率分布

\begin{tabular}{c|c|c|c}
\hline \hline & 強 & 中 & 弱 \\
\hline 強度 & $\mathrm{N}\left(6.8,1.0^{2}\right)$ & $\mathrm{N}\left(6.2,1.0^{2}\right)$ & $\mathrm{N}\left(5.8,1.0^{2}\right)$ \\
\hline 外力 & \multicolumn{3}{|c}{$\mathrm{N}\left(5.0,1.0^{2}\right)$} \\
\hline
\end{tabular}




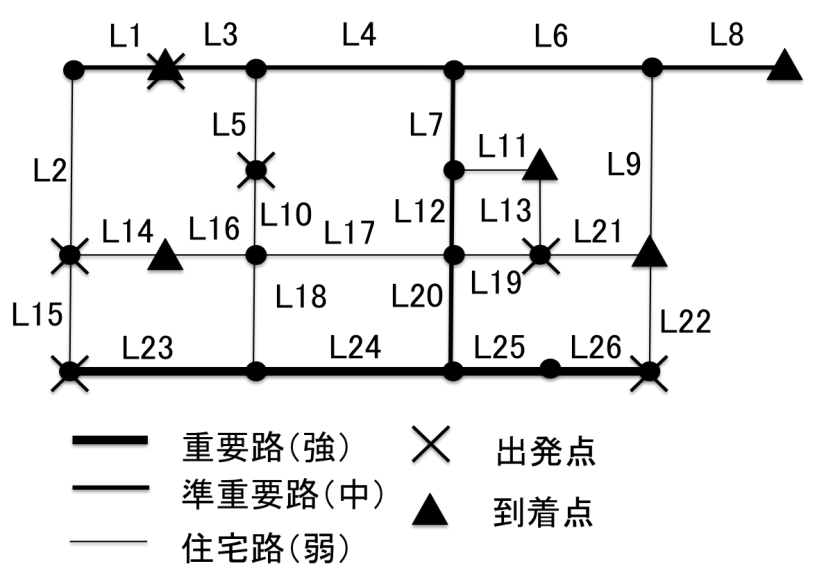

図-1＼cjkstart対象ネットワークモデル

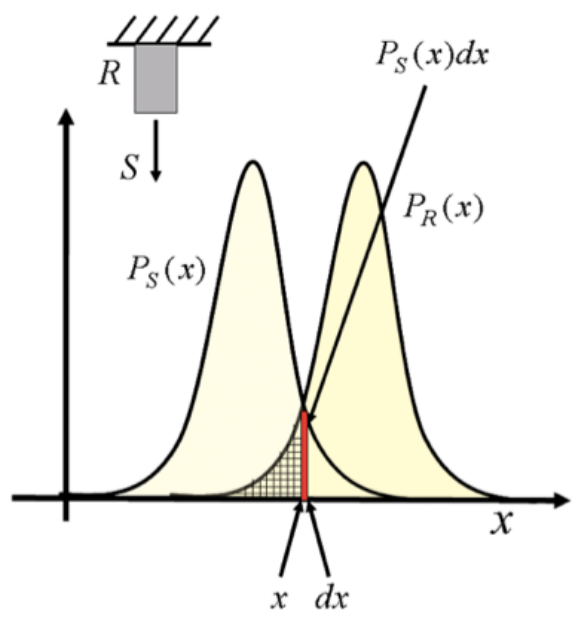

図-2 損傷の概念

まず，本研究では，既存研究 ${ }^{13)}$ におけるネットワーク の評価モデルと同様に，ネットワークの状態を各リンク の強度と外力から成る確率変数とした1つのサンプルと して扱う。強度についてはそれぞれ，現行の補強済みで ある重要路のリンクが強, 補強はされていないが利用数 が多く補修が適切に行われている準重要路のリンクを中, 住民が普段利用するような住宅路のリンクを弱とした。

ここで，本研究における強度とは，道幅の広さのよう な災害時に道路 (リンク)の機能を維持する能力を表す. また，リンクの補強とは，道路沿線の構造物に対する耐 震補強などの対策によって該当するリンクの強度分布の 平均值を大きくすることで，リンクの損傷確率が低くな るように設定し，ネットワークの稼働率を上昇させるこ とである。

本研究では，具体的な対策を選択し適用するのではな く，道路の継続性を向上させる地震対策のことを総じて 補強と表現する。そして, 本ネットワークの実際距離は 縦横で5 km以内であるため，地震時にかかる外力は，ど のリンクにおいても同じであることが予想される。した がって，本ネットワークモデルでの外力は，表-1に示す 外力の確率分布から決定され，どの地点においても同じ
值であるものとした.

本研究において, リンクの状態の決定は上述のように 表-1に示す強度分布に基づいて行われる。ここで，構造 物の損傷は，図-2で示すように強度 $R$ を持つ部材に対し て，外力 $S$ が作用する状況を仮定して判定が行われる。こ れらR，Sは共にいかなる值をとるか確定的には予測でき ない確率変数で，図に示すような確率密度関数を持つも のとする．この時，この部材に損傷が生じるのは，

$$
\begin{aligned}
& R-S>0 \rightarrow \text { 正常 } \\
& R-S \leq 0 \rightarrow \text { 損傷 }
\end{aligned}
$$

である.したがって，本研究では，表-1に示したように リンクの強度と地震による外力を確率変数として扱い, 外力が強度と同じか上回ったときに損傷が生じることと する．ネットワークの損傷判定は，各リンクの状態によ つて決定されるいくつかの地点間の連結に基づいて行わ れる. 具体的には, 出発点には住宅地や消防署, 病院を, 到着点には市が指定する各避難所を設定し，それぞれの 連結性を解析する。本章では，住宅地からは最低 1 つ, 消防署からは最低2つ, 病院からは最低3つの到着点に到 達できなければ，そのサンプルを損傷として扱う。これ により，避難や救急において孤立する箇所を考慮するこ とが可能となる.

次に，損傷と判定されたサンプルを解析することで, ネットワークの脆弱なリンクを算出する. 脆弱なリンク は, 出発点から到達点に辿り着けないルートにおいて, 辿り着くことができない要因（ボトルネック）となった リンクを探索する最小カット探索を行い，最小カットと なった回数, つまり, 連結性を失う要因のリンクとなっ た回数を加算していくことで算出する.このように連結 性を解析することで，ネットワークにおけるクリティカ ルなリンクを見つけ出す．なお，本研究における最小カ ットは, グラフ理論における最大流量問題 ${ }^{14)}$ とは異なり, 単純に出発点から到達点へと辿り着くことができない要 因を算出するものである.

以上より，現行の緊急広域交通路を重視する対策の対 象とする箇所に対策を施したネットワークの非稼働率と, 解析によって検出された脆弱なリンクに対する対策を行 つたネットワークの非稼働率との比較を行う。さらに, 住民の避難を想定し，住宅地から避難地までの避難距離 の計算を行い, より高い安全性を確保したネットワーク の構築行う。そして，本研究におけるレジリエンス性を 考慮したネットワークの評価法の有用性を示す.

（2）補強対象の推定と信頼性向上に対する影響

図-1のネットワークモデルに対して，3.(1)節で述べた 
表-2＼cjkstart脆弱なリンクと回数による順位

\begin{tabular}{ccc}
\hline \hline 順位 & リンク & 損傷回数 \\
\hline 1 & L2 & 14713 \\
2 & L10 & 13223 \\
3 & L3 & 12924 \\
4 & L16 & 12750 \\
5 & L15 & 12585 \\
\hline
\end{tabular}

表-3 非稼働率の比較（5箇所）

\begin{tabular}{c|ccc}
\hline \hline & 対策前 & 現行手法 & 提案手法 \\
\hline 非稼働率 & $49.51 \%$ & $43.78 \%$ & $30.75 \%$ \\
平均避難距離 $(\mathrm{km})$ & 1.179 & 1.181 & 1.127 \\
\hline
\end{tabular}

表-4 非稼働率の比較（8箇所）

\begin{tabular}{c|ccc}
\hline \hline & 対策前 & 現行手法 & 提案手法 \\
\hline 非稼働率 & $49.51 \%$ & $37.11 \%$ & $21.58 \%$ \\
平均避難距離 $(\mathrm{km})$ & 1.179 & 1.195 & 1.121 \\
\hline
\end{tabular}

評価法で損傷状態の解析を行う。本研究では，10,000個 のサンプルを発生させるモンテカルロシュミレーション により解析を行った. 損傷となったネットワークのサン プルにおいて，リンクの損傷回数の比較を行い脆弱なリ ンクを求めた. ネットワークにおいて脆弱なリンクであ る損傷回数が多い上位5箇所を表-2に示す.

なお，表-2におけるリンクの損傷回数は，ネットワー クの損傷と判定された1サンプルにて, 出発点から到達点 までの連結が損なわれた経路の最小カットセットに含ま れていた回数を表す。つまり，あるリンクが複数の経路 の最小カットセットに含まれていたときには重複して損 傷として回数を計上している．これにより，ネットワー クの損傷に対する影響の強さを表すことができると考え られる。

まず, 表-3は損傷回数が多かった上位5箇所について補 強を行い，再度稼働率の算出を行った結果である。これ により現行の対策に従って対象を決定する補強と比較し て, 提案手法により選定したリンクに対する補強は，ネ ットワークの非稼働率を低くできたことがわかる. 以後, 現行の対策に基づき重要路を重視し対象を決定する補強 計画モデルを現行手法，本手法により住民の安全性を重 視し対象を決定する補強計画モデルを提案手法とする. さらに，住民の避難距離もネットワークの継続性が向上 したことで短縮できた。 また，提案手法に従って補強を した後に, 再度損傷状態の解析を行った結果, L8, L11,

L13，L21，L22が脆弱なリンクとして検出された．L8の 損傷は，孤立箇所を発生させてしまう。しかしながら， ネットワークとしての継続性を考慮した今回の提案手法 では，上位の脆弱なリンクとして検出されなかった。
次に, 脆弱点に対する補強箇所を8箇所に増やし，補強 の効果について比較を行った．現行手法では，新たに準 重要路であるL1，L3，L8に補強を行い，提案手法では再 評価の際に損傷回数が多かったL5，L8，L14に補強を行 った. その結果を表-4に示す. 補強を8箇所に行った場合, 現行手法では, 5箘所の補強に比べてあまり非稼働率の差 が出なかった. 一方，提案手法では，脆弱なリンクに対 して補強を行うため, 非稼働率を低下させ，より頑健な ネットワークとすることができた．補強箇所の違いによ る避難距離への影響は, 表-3, および表-4に示すように， 提案手法によってわずかに短縮することができた。 しか しながら，現行手法の距離が増加していたことから，提 案手法の結果も誤差の可能性がある. これは, 図-1より わかるように, 用いたモデルの規模が小さく, 補強箇所 による距離の変化が現れにくいことに起因していると予 想される，そのため，規模の大きいモデルにおいて検証 が必要である.さらに, 提案手法において8箇所の補強を 行ったモデルに対して, 再度ネットワークの評価を行っ たところ，脆弱なリンクとしてL8が脆弱なリンクとして 検出された．L8では補強を行っているにも関わらず，脆 弱なリンクとして挙がっている.つまり，ネットワーク の継続性を維持するためには，最重要リンクであること がわかり，このリンクに対しては迂回路の設置などの対 策を考える必要がある.

以上のことから，本提案における備えの面に関して， 脆弱な点を把握し, その箇所に適切な対策を行うことに よるネットワークの継続性の上昇は，住民の安全性の向 上に有効であるといえる.

\section{4. 大規模道路ネットワークの評価}

\section{（1）大規模道路ネットワークの継続性評価}

3章では, 避難に求められるネットワークの稼働率に基 づいて補強対象を選定することで，その継続性と安全性 を高められることを示した。本章では大阪付近の縦横 $10 \mathrm{~km}$ の大規模ネットワークモデルに本提案を適用する. このモデルにおける外力は3章と同様に一定である. 本研 究はレジリエンスに基づく評価方法の検討であり，精度 向上を目的とするものではないため，大規模モデルにお いても外力を一定としている. そのモデルを図-3に示す.

発生させたサンプルにより, 非稼働率と住民の避難距 離を算出した. 各出発点から到達点に到達必要な数は3 章と同様に，病院は3箇所，消防は2箇所，住宅地は1箇所 とした. そして, 脆弱な箇所の上位35箇所に補強を行い, 比較した結果を表-5に示す. 実験の結果, 3章のモデルと 同様に提案手法では，現行手法よりも非稼働率を下げる ことができた．また，住民の避難距離も同様に短縮する 


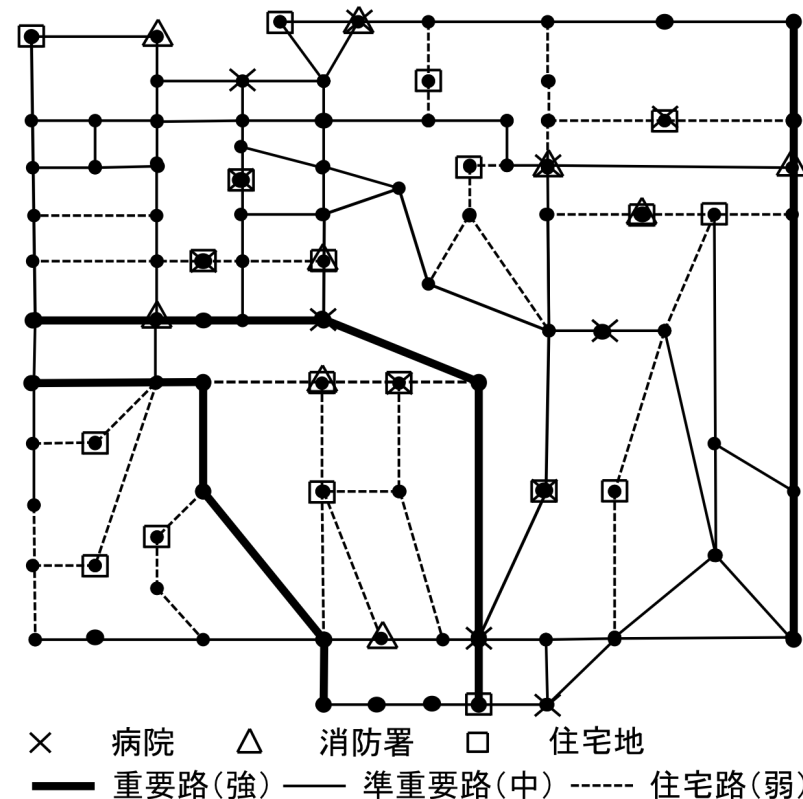

図-3大規模ネットワークモデル

表-5 非稼働率の比較

\begin{tabular}{c|ccc}
\hline \hline & 対策前 & 現行手法 & 提案手法 \\
\hline 非稼働率 & $79.32 \%$ & $76.15 \%$ & $51.93 \%$ \\
平均避難距離 $(\mathrm{km})$ & 1.306 & 1.298 & 1.257 \\
\hline
\end{tabular}

ことが可能であった．本実験において，全体的に非稼働 率が高い理由としては，ネットワークモデルにおける強 度が最も高い重要路の割合が少ないことが考えられる. そのため, モデル毎の非稼働率の減少量に注目寸ると, 本実験における非稼働率の減少量は3章のものと等しく, 損傷回数に基づく本研究の対象決定方法は有効であると いえる. また, 住民の避難距離も 3 章と同様に短縮するこ とができたが，変化量にはあまり差異が見られなかった ため，規模は避難距離にさほど影響しないといえる.

\section{(2) 道路ネットワークの復旧}

4.(1)節では, 3 章で用いた評価法によって大規模ネット ワークモデルの評価を行った，その結果，非稼働率を減 少させることができた. ここでは，4.(1)節での実験に加 えて, 復旧日数を算出することで, 対応の面でのレジリ エンス性の向上に対する有効性を示す.

本研究における復旧は，ネットワークのノードを構造 物として扱い, 損傷の有無を確率変数によって発生させ, 設定した復旧班が損傷した構造物の復旧を行うものとす る. そして，復旧開始から，全ての構造物の復旧が終わ るまでの復旧日数を算出し比較する. 構造物の復旧日数 を用いることで，ネットワークの継続性が復旧班の移動 時間に影響を与え, 復旧日数に差が生まれると推測され る. 構造物の損傷状態は, 3.(1)節のリンクの損傷判定法
表-6 被害度と被害量

\begin{tabular}{cccc}
\hline \hline 被害度 & 小 & 中 & 大 \\
\hline 被害量 & 200 & 300 & 500 \\
\hline
\end{tabular}

表-7 復旧班の詳細

\begin{tabular}{c|rrrrrr}
\hline \hline 復旧班 (ID) & 1 & 2 & 3 & 4 & 5 & 6 \\
復旧能力 (/時) & 30 & 20 & 10 & 10 & 30 & 20 \\
待機場所 (No.) & 1 & 8 & 23 & 31 & 43 & 55 \\
\hline \hline 復旧班 (ID) & 7 & 8 & 9 & 10 & 11 & 12 \\
復旧能力 (/時) & 10 & 10 & 30 & 20 & 10 & 10 \\
待機場所 (No.) & 59 & 64 & 78 & 87 & 46 & 71 \\
\hline
\end{tabular}

表-8 復旧日数の比較

\begin{tabular}{c|ccc}
\hline \hline & 対策前 & 現行手法 & 提案手法 \\
\hline 平均 & 13 & 12 & 9 \\
最短 & 3 & 3 & 3 \\
最長 & 46 & 43 & 39 \\
\hline
\end{tabular}

と同様に, 確率変数を用いて式(1a), および式(1b)によっ て算定する。 また，強度分布も同じように表-1に従い， 4.(1)節において病院としていたノードの強度を強，消防 署を中，その他を弱とした，さらに，確率変数によって 算出された数值によって被害度を設定し，それを基に被 害量を設定した。これを表-6に示す，また，本実験にお いて用いた復旧班の詳細を表-7に示寸.

復旧班は, 待機場所と復旧能力, 1 日における活動可能 時間を持ち, 待機場所から被害を受けた箇所一の移動時 間を考慮しながら, 活動可能時間内において復旧を行う。 復旧順序は, 構造物ごとに予め設定してある重要度の降 順と寸る.また，復旧作業量は活動した時間に復旧能力 を掛けた值とし，それを構造物の被害量から減算してい く.そして, 被害量が0以下となった構造物は, 復旧完了 となる。 それらを全ての復旧班について行い, 全ての復 旧班の活動時間が0になった時点で，1日分の作業が完了 したものし, 全ての構造物の被害量が 0 , つまり完全に復 旧するまでにかかる日数を算出する。 また，ネットワー クの分断により, 被害を受けた箇所一復旧班が到達不可 能となる可能性がある。これによる復旧計画の破綻を防 ぐために, 目的箇所に到達不可能な班は次に重要なリン クの復旧を行うものとした，重要なリンクは，リンクの 強度を高く設定したリンク,つまり重要路から準重要路, 住宅路の順に行った. 以上のように復旧シミュレーショ ンを定式化し，図-3のネットワークに対して，復旧日数 を算出する.

\section{(3) 実験結果}

4.(2)節で述べた復旧シミュレーションにより, 現行手 
法と提案手法それぞれの補強モデルにおいて10,000個の サンプルを用いて復旧シミュレーションを行った結果を， 表-8に示寸. 平均, 最短, 最長復旧日数はそれぞれ, 10,000 個のサンプルより得られた数值である.

提案手法のモデルは, 他のモデルよりも平均復旧日数 を短縮することができた．ネットワークの継続性を考慮 した対策は構造物の孤立を防ぎ，復旧班が滞りなく被災 箇所へ到達して作業できるようになったからであると推 測される. 最長復旧日数も, 平均復旧日数と同じように 短縮することができた. しかしながら, 最長復旧日数は, 短縮しても1ケ月の日数が必要である. これは, リンクの 分断による被災箇所の孤立が発生し, 復旧班が辿り着く ことができずに，日数が経過してしまったことによるも のであると考えられる．実際には，全ての箇所を均等に 補強することは難しいことから，本実験のように復旧班 が辿り着けずに数日経過してしまう箇所が発生しうる. そのため，孤立箇所に関しては，物資を事前に準備して おくなどの対策が必要であるといえる，本研究では，リ ンクの復旧は重要度が高いものから一定の日数毎に復旧 を行っている，そのため，孤立した構造物に辿り着くた めのリンクについて復旧が後回しにされてしまい, 全体 の復旧日数が延びてしまったと考えられる.したがって, リンクの復旧順序に関しても, 重要度により復旧順序を 決めるだけではなく, 被災箇所の孤立を優先した復旧順 序の決定方法を考える必要がある.

提案する補強モデルにおける復旧では，ノード間の連 結性を向上させることができる，そのため，復旧班が被 災箇所に到達不可となる事態に陥ることを少なくするこ とができ, 本提案における対応の面に関しても, ネット ワークの継続性を向上させることは有効であるといえる.

\section{5. おわりに}

本研究では，地震に対するレジリエンス性を考慮した 道路ネットワークの評価を試みた。道路をネットワーク として捉え, 補強対象の選定を行うことによって, 重要 路に対してだけ補強を行っていくよりも，地震に対する 事前の備えと事後の対応力を高められることを示した. よって, 現行の補強モデルと本研究に従う補強モデルと いう二つのモデルのネットワーク継続性と復旧力, 住民 の安全性を提示し比較することで，対策の相対的な効果 の検証とレジリエンス性を評価できることを示せたとい える.

リンクの強度を上昇させるための具体的な対策は適用 するモデルに依存するため, 本提案では対策方法の選択 までは扱わなかった。 しかし，ネットワークにおける脆 弱な点を明らかにすることで, 地震対策において重要路
以外の道路も視野に含め, 道路網をネットワークとして 地震対策を考えるべきであるという側面を示した.

災害対策は，市民の理解を得た上で行うことが必要で ある. 本提案は，対策ごとの効果を明らかにすることが できる，よって，防災計画の効果を明らかにし，市民一 の説明や対策に関する議論に有効と考えられる. 補強対 象の決定は, 日々の利用者数などの理由から, 住宅路を 優先して対象とすることは難しい，しかし，住民の安全 性は考慮されなければならない要素である。 そのため, 対策対象の選定とその有效性を様々な角度から示寸こと が必要とされる.これにより, 早急に対処できない脆弱 性に対して, 防災教育として市民への備えを施すといっ た異なる観点から解決策を検討することができる．した がって, シミュレーションによる予見は, 本提案のよう にレジリエンスに基づく指標を加え, 議論の中で用いる ことで，地震対策の効果を高めていくことができると考 えられる.

今後の課題として, 既存研究の復旧日数の最適化 ${ }^{15)}$ 組み合わせることや，レジリエンスの有効性を明確なも のとするために，定量的な評価が必要であることが挙げ られる. 本研究においては, 相対的にレジリエンスを示 したが，レジリエンスの評価方法の明確化には至らなか った. レジリエンスは，未だに一つの定義に留まってお らず，研究を進めていく中で，今後レジリエンスを視野 に含めた地震対策の議論を通し, 明確にしていくことが 必要であると考える.

本研究では, 主に地震対策のようなハードな面に着目 してレジリエンスの評価を試みた。しかしながら，道路 ネットワークのシステムとしてのレジリエンスは, 防災 教育のようにソフトな面からの向上も必要である.これ に関しては, 文献 16)において, 学習, 対処, 監視, 予 見の 4 つのプロセスからシステムのレジリエンスを考慮 寸る必要性が述心゙られている. この考えにおいても本提 案による評価は有効と予想されるため, より広い視点か ら地域のレジリエンス向上に取り組む予定である.

\section{参考文献}

1)内閣官房国土強勒化推進室： http://www.cas.go.jp/jp/seisaku/kokudo_kyoujinka/, 内閣 官房, 2014.

2) Holling, C. : Resilience and stability of ecological systems, Annual Review of Ecology and Systematics, 4, 1-23, 1973.

3) Birkmann, J. : Measuring Vulnerability to Natural Hazards Towards Disaster Resilient Societies, 2006.

4) Norris, Fran H., Susan P. Stevens, Betty Pfefferbaum, Karen F. Wyche and Rose L, Pfefferbaum. : Community Resilience as a Metaphor, Theory Set of Capacities and Strategy for Disaster Readiness, 736American Journal of Community Psychology 41, 
pp.127-150, 2008.

5) Bruneau, M., et al. : A Framework to Quantitatively Assess and Enhance the Seismic Resilience of Communities. Earthquake Spectra, 19-4, 2003.

6) 日本規格協会. JIS Q 2001：2001 リスクマネジメントシス テム構築のための指針，2003.

7) SCOPE NET : 災害リスクをマネジメントする, 港湾空港 建設技術サービスセンター，2013.

8) 財団法人ひょうご経済研究所 :「震災クライシスマネジメ ントとその実践」阪神・淡路大震災の教訓から，2006.

9）若林拓史 : 地震災害時における道路網連結信頼性と確率重 要度による耐震強化重要区間の決定法, 1995.

10）能島暢呂, 山中敏裕 : 道路ネットワークの地震時機能信頼 性解析に基づく施設改善の重要度評価, 1998.

11）高山純一，黒田昌生，飯坂貴宏，藤澤正子 : 震災時におけ る消防車の走行時間信頼性，2000.

12）増井周平, 尾曽真理恵, 柳沢吉保, 古本吉倫, 高山純一： 信濃川断層を考慮した被災時救急搬送サービスの信頼性 評価に関する研究，2010.

13）三宅健太, 古田均, 佐藤忠信, 築山勲 : マルコフ連鎖モン テカルロ法と Subset 法を用いたネットワークの信頼性解 析，学術講演会講演論文集，Vol.56，pp.169-170， 2007.

14）永持仁，石井利晶，茨木俊秀 : 最小カッ卜問題の簡潔かつ 構成的な証明, 情報処理学会研究報告. AL, アルゴリズム 研究会報告 96(100), 33-40, 1996-10-17.

15）古田均，中津功一朗，野村泰稔，不確実性を考慮した被災 ネットワークの復旧計画策定, 土木学会論文集 A, vol.64, No2, p.434-445, 2008.5.
16) Hollnagel, E., Paries, J., Woods, D. D. and Wreathall, J. (編著)， 北村正晴，小松原明哲（監訳）：実践レジリエンスエンジ ニアリング 社会・技術システムおよび重安全システムへ の実装の手引き，日科技連出版社，2014.

(2014.7. 18 受付)

\section{Evaluation of Earthquake Preparedness by Analyzing the Reliability of Road Network in Consideration of Regional Resilience}

\section{Hitoshi FURUTA, Koichiro NAKATSU, Kyosuke TAKAHASHI, Ken ISHIBASHI and Yoshiaki KAGAWA}

This study attempts to evaluate the effectiveness of earthquake preparedness to the improvement of regional resilience by analyzing the reliability of road network based on the safety of human life. This reliability analysis extracts vulnerable points to the reachability of fire truck and ambulance and the evacuation of residents. By comparing the reinforcement of extracted elements with the ongoing plan, this paper demonstrates that the proposed preparedness based on the regional resilience more improves the safety of residents with the enhancement of the continuity of road network. The assessment of earthquake preparedness from various viewpoints is necessary to predict and minimize the seismic crisis. In this paper, it was implied that the evaluation that put a priority on the human life could be a criterion for the improvement of regional resilience. 